\title{
Assessment of phytotoxicity of leachates from landfilled waste and dust from foundry
}

\author{
Marta Bożym ${ }^{1}$ \\ Accepted: 15 March 2020 / Published online: 14 April 2020 \\ (C) The Author(s) 2020
}

\begin{abstract}
The study assesses the contamination, classification and phytotoxicity of foundry waste. The presented results are a part of the research on the agrotechnical use of foundry waste. Landfilled foundry waste (LFW) and dust samples were taken from one of the Polish foundries. An analysis of the waste and its leachate composition was conducted. Phytotoxicity tests were carried out using Lepidium sativum. The aim of the phytotoxicity study was to evaluate germination and root growth after $72 \mathrm{~h}$ and the accumulation of heavy metals after 7 days. LFW was least contaminated with heavy metals and metalloids compared to dust. The composition of the foundry dusts depended on the unit of the foundry, from which it was collected. It was found that electric arc furnace dust (EAFD) was the most polluted by heavy metals among the dust samples. According to the requirements of Polish regulations most of tested waste were classified as non-hazardous, and EAFD as hazardous waste due to high $\mathrm{Pb}$ concentration in leachate. Phytotoxicity tests have shown a low phytotoxicity of the leachate from most of the tested waste. The results of the accumulation test showed that an excess of metal and metalloids in leachate was not directly related to its accumulation in plants. A negative correlation between $\mathrm{EC}, \mathrm{Cu}, \mathrm{Co}, \mathrm{Fe}, \mathrm{Pb}, \mathrm{Cr}, \mathrm{K}$, $\mathrm{Na}$, sulfate, fluoride, ammonia, phenol and formaldehyde concentration in leachate and GI was found. It was stated that the $\mathrm{Fe}, \mathrm{Mn}$, As and Se in plants was significantly correlated with concentrations in leachate.
\end{abstract}

Keywords Foundry waste $\cdot$ Dust $\cdot$ Heavy metals $\cdot$ Phytotoxicity $\cdot$ Germination index $(\mathrm{GI}) \cdot$ Lepidium sativum

\section{Introduction}

One of the main directions of minimizing the negative impact of foundries on the environment is decreasing of waste generation and its reuse. Foundry waste mainly includes spent foundry sands (SFS). Moreover foundries also generate other waste such as dust and sludge from dust collectors, smelter slags, residue of refractory materials and spent grinding materials. About 600,000 tonnes of foundry waste are produced annually in Poland, including about 500,000 tonnes are waste from the iron foundry. Foundry waste, especially SFS, can be reused, e.g. in foundry

Supplementary information The online version of this article (https:// doi.org/10.1007/s10646-020-02197-1) contains supplementary material, which is available to authorized users.

Marta Bożym

m.bozym@po.edu.pl

1 Opole University of Technology, Prószkowska 76 Street, Opole 45-758, Poland production, in the construction and road industry. In addition, the use of SFS as a soil substitute is popular in the US and other countries (Dungan et al. 2006; Dayton et al. 2010). Foundry dusts can also be reused, e.g. in the production process of castings, in construction or to fill closed mines and excavations as inert material (Bożym and Dąbrowska 2012; Bożym 2018). The ability to reuse foundry dust depends on the composition and content of the contaminants. Dust is collected at various stages of casting production, e.g. while smelting metal in furnaces, cleaning casting and during SFS regeneration. Electric arc furnace dust (EAFD) is usually collected in a baghouse and amounts to $\sim 2 \%$ of the steel produced (Strobos and Friend 2004). EAFD is one of the most hazardous industrial waste (Strobos and Friend 2004; Salihoglu and Pinarli 2008; Mymrin et al. 2016). This is related to the high content and potential leaching of heavy metals. In some cases it is profitable to recover metals from these dusts (Strobos and Friend 2004). EAFD can be reused in the production of castings and in metallurgy or for the production of Portland cement (Škvára et al. 2002; Mymrin et al. 2016). The EAFD can also be solidified with lime and concrete, in order to 
reduce the leachability of heavy metals, and landfilled (Andrés et al. 1995; Hamilton and Sammes 1999). The composition of dust from the regeneration unit depends mainly on the type of molding sand and binder. This dust is usually classified as inert and used in construction and road construction or due to the high content of residue of organic binder, it can be used as a fuel in cement plants (Bożym 2018).

The basic criteria for classifying waste for landfilling or for assessing applications for its use is the leachability of contaminants. The main contaminants in foundry waste are heavy metals (Bożym 2017, 2019) and organic compounds, formed as a result of the thermal decomposition of organic binders. Organic binders include phenolic, furan, phenol-formaldehyde, phenol-urethane, urea resins, furfuryl alcohol and other. For this reason, phenol, formaldehyde or cyanide may be present in foundry waste leachate (Lilja and Liukkonen 2008). In Poland waste classification is based on the quality of water extracts (leachate). Polish waste is classified as (1) inert, (2) non-hazardous and (3) hazardous (Journal of Law 2015). It turns out that physicochemical analyses are not enough to assess the toxicity of waste, because many contaminants can affect each other (García-Gómez et al. 2014b). Therefore, ecotoxicological methods are used, which indicate the impact on biota (García-Lorenzo et al. 2009). Widely used ecotoxicological methods include organisms from all levels of the food-chain, e.g. aquatic organisms for waste-water or leachate assessment (Quilici et al. 2004), earthworms for soil contamination assessment (Quilici et al. 2004; García-Gómez et al. 2014a; Curieses et al. 2016), snails for contaminated area assessment (Dallinger et al. 2004). One of the varieties of ecotoxicity tests is based on the use of plants, these are called phytotoxicity tests. These tests are mainly based on the assessment of apical endpoints such as germination, root growth and/or plant growth rate. In recent times, new protocols have been developed to determine the effects of toxins which are based on biochemical alterations, these are termed biomarkers. Among them, are biomarkers sensitive to heavy metals which have an impact on various biochemical processes in plants, e.g. enzyme and antioxidant production, oxidative stress protein mobilization and photosynthesis (Liu et al. 2009; Wang et al. 2010; Gupta et al. 2013; Alonso-Blázquez et al. 2015; Hu et al. 2015; Oztetik 2015; Rout et al. 2015; Seneviratne et al. 2019). In the phytotoxicity assessment of waste, leachate is usually tested, because nutrients and pollutants may be uptaken by the plants directly from aqueous solutions, in dissolved form. Contaminants in leachate can directly affect the germination of seeds and the development of seedlings, because plant growth depends directly on the medium. It is considered that seed germination bioassay could be less sensitive to toxic substances than root growth tests (Fuentes et al. 2004). Some authors suggest that toxic substances may not be absorbed by seeds, because the embryon (germ) of seeds is effectively isolated from the environment and draws nutrients (carbohydrates, macro- and microelements) from the seed (Mitelut and Popa 2011; Seneviratne et al. 2019). The roots are responsible for the absorption of water and nutrients, for this reason root lengths are affected by the concentration of the contaminants present in the water solution. The OECD guidelines (OECD 2006) provide many terrestrial plant species used to assess phytotoxicity. Mañas and De las Heras (2018) suggest that it is difficult to choose the appropriate plant species to analyse phytotoxicity. The authors propose that a general agreement should be reached between researchers in order to standardize this type of analysis. One of the most frequently used plants for phytotesting is garden cress (Lepidium sativum). The advantage of this species is the availability of seeds, rapid growth, sensitivity to environmental factors, including heavy metals, and low humidity requirements. Lepidium sativum is a recommended plant in many standards for biotoxicity test (Baumgarten and Spiegel 2004) and is used by many authors (Hoekstra et al. 2002; Fuentes et al. 2004, Barrientos et al. 2012; Baran et al. 2014; Visioli et al. 2014; Baran and Tarnawski 2015; Wierzbicka et al. 2015; Praveen et al. 2017; Khan et al. 2018; Mañas and De las Heras 2018; Seneviratne et al. 2019).

The aim of the study was (a) the analysis of the content of contaminants in the foundry waste and its leachates, (b) waste classification based on leachate quality, (c) a phytotoxicity assessment of leachates on the basis of germination and root length test, and (d) the assessment of the impact of leachate on plant growth and heavy metals, metalloids and nutrients accumulation.

\section{Material and methods}

\section{Foundry}

The foundry is located in south-west Poland (N 50 $40^{\prime}$ 20.5853; E $18^{\circ} 12^{\prime} 44.7181^{\prime \prime}$ ). The foundry produces parts for machine and industrial equipment from cast steel and cast iron. The foundry was the owner of two industrial waste landfills (heaps). According to data from 2003, 3.5 million tonnes of waste were landfilled on both heaps. At the beginning of the 2000s, a company which specializes in the production of road aggregates started waste recovery. Up to now, waste recovery at both heaps is being carried out. Metal, refractory materials, and parts of graphite electrodes are recovered. However, landfilled foundry waste (LFW) is mainly recovered and used for aggregate production. The main component of LFW are SFS. In addition, other foundry wastes are a component of LFW, e.g. slag, 


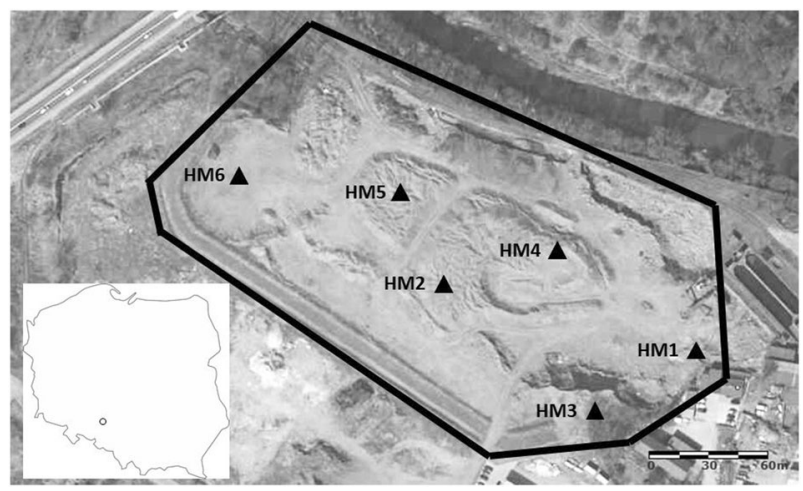

Fig. 1 Location of the foundry and foundry waste landfill with sampling points (HM1-HM6). Source of maps: www.google.pl/maps

spent refractory material, metal inclusions, sludge and dust from dust collectors and sinters. Currently, the foundry owns one landfill. As a result of many years of waste recovery, this landfill has reduced its area from 8.8 to 4.7 ha. Figure 1 shows the location of the foundry and landfill. Additionally, sampling points at the landfill were presented. Foundry samples were taken from the waste landfill (LFW) and dust collectors from various foundry units.

\section{Sampling}

LFW samples were collected in November 2017 from an industrial waste landfill, owned by the foundry. Samples were taken from six piles $(n=6)$, which were separated during material recovery, by a screening and sorting machine. Each cone-shaped pile was characterized by a height of about $3 \mathrm{~m}$ and a base diameter of about 3-4 m. Samples were taken from 4-5 places of each pile, from a depth of $25 \mathrm{~cm}$, about $5 \mathrm{~kg}$, creating a increment sample with a mass of about $25 \mathrm{~kg}$. The increment sample was mixed and quartered to form a laboratory sample of $\sim 5 \mathrm{~kg}$. After transport to the laboratory, the material was dried at room temperature, sieved through a $4 \mathrm{~mm}$ (PN-EN 12457-2: 2006), ground in a mortar and again sieved to $1 \mathrm{~mm}$.

The dust samples were collected in terms from 23.11.2017 to 12.01.2018 from the dust collectors of three foundry units: the forming unit, steelworks (induction furnaces) unit and shot blasting unit). Samples were given the appropriate numbers $(\mathrm{P} 1-18)$. The characteristics of the dust sampling location, dust collector of forming unit: P1 and P18 - shock grating dust (SGD), P2 and P16-regeneration of spent foundry sands dust (RD), P3 and P17-transport (of molding sands) dust (TD), steelworks unit: P4 and P14 -electric arc furnace dust (EAFD); shot blasting unit: P5-P13 and P15-pneumatic blast cabinet dust (PBCD). Dust samples were not sieved. The foundry uses bag dust collectors and cassette dust collectors with pulse and jet filters. Dusts from the foundry are forwarded to external firms and used in metallurgy (EAFD and dust from pneumatic treatment of castings) or as filling in closed mines, as inert material (other dust).

\section{Phytotoxicity tests}

\section{Germination test}

The germination tests were conducted based on the methodology of Zucconi's test (Zucconi et al. 1981). The commercially available, certificated (PL-EKO-01) seed material of Lepidium sativum were used. The seeds were not pretreated. Twenty undamaged seeds of almost identical sizes were placed on a Whatman \#1 filter paper in a $90 \mathrm{~mm}$ Petri dish, and $5 \mathrm{~mL}$ of waste leachate samples were added. Seeds were placed uniformly on the surface of a filter paper at the bottom of a Petri dish. As a control sample, Petri dishes were prepared as for leachates from foundry waste, only deionized water was added. The Petri dishes were covered and incubated at $20-25{ }^{\circ} \mathrm{C}$ in the dark. The number of germinated seeds was then counted and the elongation of the roots was measured after $72 \mathrm{~h}$. The germination tests were conducted in triplicate, and the errors were recorded as standard deviations (SD). The germination index (GI) was calculated as RRG and RSG quotient up to $100 \%$ using Eq. (1) (Tiquia 2000):

$$
G I \%=\frac{R S G \times R R G}{100}
$$

where, RSG - relative seed germination (\%), RRG relative root growth (\%). RSG and RRG were calculated using Eqs. (2) and (3), respectively:

$$
R S G \%=\frac{G n}{G c} \times 100
$$

where, Gn and Gc were the mean values of the number of seeds germinated in waste leachate and deionized water, respectively,

$R R G \%=\frac{L n}{L c} \times 100$

where, Ln and Lc were the mean root length in the waste leachate and deionized water, respectively.

The root length was measured from the tip of the root to the radicle, with an accuracy of $1 \mathrm{~mm}$.

\section{Accumulation test}

As part of the phytotoxicity tests of the foundry waste, an experiment on the accumulation of heavy metals, metalloids 
and nutrients in plants was carried out. The Petri dishes were filled with cotton wool and moistured with waste leachate $(10 \mathrm{ml})$. The cotton wool was previously washed with deionized water for $24 \mathrm{~h}$ and dried at $105^{\circ} \mathrm{C}$. Then $1 \mathrm{~g}$ $\pm 0.1 \mathrm{~g}$ of Lepidium sativum seeds were added. Seeds were placed uniformly on the surface of a cotton wool at the bottom of a Petri dish. The experiment was conducted for 7 days. Every day, $1 \mathrm{ml}$ of leachate or deionized water (control) was added to each dish, respectively. The dishes were kept at room temperature in the light $(16 \mathrm{~h})$ and in the dark $(8 \mathrm{~h})$. Every day of the experiment the growth and development of plants was observed. After this time the plants were separated from the cotton wool. The plant material was dried at $105^{\circ} \mathrm{C}$ and grinding in a mortar. The dry mass of plants was mineralized and analysed. The accumulation test was carried out in triplicate for each waste sample.

Due to the adsorption properties of cotton wool, an experiment to determine the degree of pollution adsorption by cotton wool for each leachate was carried out. This experiment analogously to the accumulation test without sowing seeds was carried out. A correction factor as "cotton controls", for each leachate has been included to provide free contaminants available for seeds. The percentage reduction of metal, nutrient and metalloid concentration in the leachate before and after adsorption by cotton wool is given in Table 1.

Table 1 'Cotton controls' presented as correction factor [\%] of metals and metalloids adsorbed by cotton wool from leachate

\begin{tabular}{lllllll}
\hline Metal (loid) & \multicolumn{3}{l}{ Cotton controls } & & & \\
\cline { 2 - 6 } & LFW & SGD & RD & TD & EAFD & PBCD \\
\hline $\mathrm{Cd}$ & n.c. & 101 & 99 & 97 & 98 & 97 \\
$\mathrm{~Pb}$ & n.c. & 93 & 90 & 97 & 95 & 95 \\
$\mathrm{Cu}$ & 95 & 93 & 92 & 94 & 93 & 91 \\
$\mathrm{Zn}$ & 96 & 98 & 99 & 96 & 85 & 88 \\
$\mathrm{Cr}$ & 86 & 92 & 83 & 90 & 84 & 86 \\
$\mathrm{Ni}$ & 98 & 95 & 92 & n.c. & 96 & 91 \\
$\mathrm{Mo}$ & 98 & 93 & 93 & 95 & 98 & 95 \\
$\mathrm{Co}$ & 96 & 93 & 89 & 95 & 94 & n.c. \\
$\mathrm{Fe}$ & 94 & 94 & 96 & 97 & 89 & 96 \\
$\mathrm{Mn}$ & 89 & 97 & 98 & 91 & 91 & 96 \\
$\mathrm{As}$ & 98 & 95 & 103 & 94 & 92 & 94 \\
$\mathrm{Sb}$ & n.c. & n.c. & n.c. & n.c. & n.c. & n.c. \\
$\mathrm{Se}$ & n.c. & 101 & n.c. & 99 & 97 & 100 \\
$\mathrm{Ca}$ & 85 & 85 & 84 & 89 & 91 & 86 \\
$\mathrm{Mg}$ & 94 & 88 & 87 & 91 & 91 & 89 \\
$\mathrm{~K}$ & 94 & 91 & 98 & 92 & 91 & 93 \\
$\mathrm{Na}$ & 104 & 109 & 105 & 104 & 104 & 104 \\
\hline
\end{tabular}

value $<$ LOQ

n.c. not calculated

\section{Analysis of leachates}

A leachate from LFW and dust samples were prepared in the ratio 1:10 $(24 \mathrm{~h})$ in accordance with PN-EN 12457-2: 2006. In leachates from waste and dust as well as in deionized water the following were determined: $\mathrm{pH}$ by potentiometric method (Elmetron CPC-501), electrical conductivity (EC) by the conductometric method (Elmetron CPC-501), sulfate(VI) concentration by the turbidimetry with barium chloride and the spectrophotometric method concentration of: chlorides with mercury thiocyanate, fluoride with SPADNS, formaldehyde with phenylhydrazine, phenol with phenyl hydrazine, cyanides with barbituric acid and pyridine, using UV-1601pc spectrometer (Shimadzu) according to Polish standards. Each sample was analyzed in triplicate.

\section{Heavy metals, metalloids and nutrient analysis}

LFW samples were mineralized with aqua regia $(9 \mathrm{ml} 36 \%$ $\mathrm{HCl}$, Avantor, and $3 \mathrm{ml} 65 \% \mathrm{HNO}_{3}$, Merck) according to the methodology 'Soil' (Millestone): $200{ }^{\circ} \mathrm{C} 10 \mathrm{~min}$., $200{ }^{\circ} \mathrm{C} 15 \mathrm{~min}$. (1000 W), $30 \mathrm{~min}$. cooling. Dust samples were mineralized with $4 \mathrm{ml}$ of $\mathrm{HNO}_{3}(65 \%$, Merck), $3 \mathrm{ml}$ of $\mathrm{H}_{2} \mathrm{SO}_{4}(96 \%$, Merck) and $3 \mathrm{ml}$ of $\mathrm{HF}$ (70\%, Avantor) according to the method of 'Saw dust with oil' (Millestone): $200{ }^{\circ} \mathrm{C} 10 \mathrm{~min} ., 220^{\circ} \mathrm{C} 20 \mathrm{~min} .(1000 \mathrm{~W}), 30 \mathrm{~min}$. cooling. Plant samples of Lepidium sativum were mineralized with $7 \mathrm{ml} \mathrm{HNO}_{3}\left(65 \%\right.$, Merck) and $2 \mathrm{ml} \mathrm{H}_{2} \mathrm{O}_{2}$ (30\%, Avantor) according to the methodology 'Dried plant tissue' (Millestone): $200^{\circ} \mathrm{C} 10 \mathrm{~min} ., 220^{\circ} \mathrm{C} 10 \mathrm{~min} .(1000 \mathrm{~W}), 30 \mathrm{~min}$. cooling. The leachate were acidified with $\mathrm{HNO}_{3}(65 \%$, Merck). Heavy metals (Cd, $\mathrm{Pb}, \mathrm{Cu}, \mathrm{Zn}, \mathrm{Cr}, \mathrm{Ni}, \mathrm{Fe}, \mathrm{Mn}, \mathrm{Mo}$, $\mathrm{Co}$ ), metalloids (As, $\mathrm{Se}, \mathrm{Sb}$ ) and nutrients $(\mathrm{Ca}, \mathrm{Mg}, \mathrm{K}, \mathrm{Na})$ in the leachates and digest solutions were analysed using a Thermo atomic absorption spectrophotometer (Solaar 6) with FAAS technique. Each sample was analyzed in triplicate.

\section{Quality control and correlation analysis}

For quality control of total heavy metals, metalloids and nutrients content in the leachate, mineralizates and plant samples, certified reference materials (CRM) mineralized in accordance with the above methodology were analysed. Due to the similarity of LFW to soils, soil CRM was used in the study. Four CRM materials were analysed: 1) 'Metals in soil' SQC001 (Merck), 2) 'Urban particulate matter' SRM 1648a (Sigma Aldrich), 3) 'Fine dust (PM10-LIKE)' (IRMM) ERM $^{\oplus}-$ CZ120 and 4) 'Lichen (trace elements)' BCR-482 (IRMM). Recoveries obtained for metals and metalloids ranged between 90 and $115 \%$. Additionally, a testing material (ICP multielement standard solution XI, 
Merck) to quality control of metal analysis in aqueous solutions was analysed. An analysis of variance (ANOVA) was used to determine significant differences $(p<0.05)$ between the control and tested samples. The correlation between the content of metals and metalloids in the leachate and Lepidium sativum and between the GI and the concentrations of various chemical constituents in the leachates was assessed using correlation matrices test and Pearson's correlation analysis with STATISTICA version 13.3 software.

\section{Results and discussion}

\section{Characteristics of waste}

Table 2 shows the total content of heavy metals, metalloids and nutrients in the tested waste. The LFW were characterized by a low content of heavy metals and metalloids compared to dusts. The content of heavy metals in LFW was at the level of naturally occurring concentrations in soils around the foundry (Bożym et al. 2009). In the tested dust samples, including heavy metals and metalloids, a high content of $\mathrm{Zn}$ and $\mathrm{Cu}$ was found. EAFD samples were also characterized by a high Pb content ( $2500 \mathrm{mg} / \mathrm{kg} \mathrm{DM})$. Due to their high content of heavy metals, EAFDs are most often classified as hazardous waste (Strobos and Friend 2004; Salihoglu and Pinarli 2008; Mymrin et al. 2016). In percentage basis, iron was the dominant component of the tested waste. The highest iron percentages were determined in PBCD and EAFD. The composition of PBCD is primarily affected by grinding shots (steel shots), used to clean castings. The composition of EAFD depends on the electric arc furnace input (steel scrap), because during the melting process, certain elements volatilize, and after cooling, these elements form a fine dust (Andrés et al. 1995; Hamilton and Sammes 1999; Škvára et al. 2002; Salihoglu and Pinarli 2008). The tested EAFD was also characterized by a high content of Mn. Other dust samples did not contain significant amounts of Mn. Among various nutrients, a high content of calcium and magnesium and a low content of sodium and potassium in LFW samples was determined. The source of $\mathrm{Ca}$ and $\mathrm{Mg}$ in LFW may be refractory materials and waste from furnace lining. A higher $\mathrm{K}$ and $\mathrm{Na}$ content was found in dust samples-SGD, TD and EAFD. The content of metalloids in all samples was low.

\section{Characteristics of the leachate}

Table 3 presents the results of the leachate analysis of the tested waste compared to the Polish waste classification standard. The $\mathrm{pH}$ of leachate from the tested waste had a wide range, especially dust leachate: from acidic ( $\mathrm{pH} 5.2)$ to alkaline ( $\mathrm{pH}$ 9.2). LFW leachate was slightly alkaline (mean $\mathrm{pH}=7.7)$. The EAFD samples were characterized by a range of $\mathrm{pH}, 6.5(\mathrm{P} 4)$ and $8.6(\mathrm{P} 14)$. Electrical conductivity (EC) is a parameter that determines the salinity of leachate. High salinity has a negative impact on the environment, especially on seed germination and plant growth. It turns out that plant resistance to environmental salinity depends
Table 2 Total content of metal/ metalloids in foundry waste $($ mean $\pm \mathrm{SD})$

\begin{tabular}{lllcccc}
\hline Metal (loid) & Samples & \multicolumn{5}{l}{} \\
\cline { 2 - 6 } & LFW & SGD & RD & TD & EAFD & PBCD \\
\hline $\mathrm{Cd}[\mathrm{mg} / \mathrm{kg} \mathrm{DM}]$ & $<0.2$ & $<0.2$ & $1.4 \pm 1.3$ & $7.0 \pm 1.3$ & $32.6 \pm 6.5$ & $1.0 \pm 1.3$ \\
$\mathrm{~Pb}[\mathrm{mg} / \mathrm{kg} \mathrm{DM}]$ & $33 \pm 13$ & $102 \pm 73$ & $31 \pm 10$ & $70 \pm 21$ & $2429 \pm 92$ & $13 \pm 6$ \\
$\mathrm{Cu}[\mathrm{mg} / \mathrm{kg} \mathrm{DM}]$ & $78 \pm 56$ & $1024 \pm 789$ & $608 \pm 84$ & $384 \pm 144$ & $1208 \pm 85$ & $415 \pm 205$ \\
$\mathrm{Zn}[\mathrm{mg} / \mathrm{kg} \mathrm{DM}]$ & $98 \pm 24$ & $1600 \pm 267$ & $900 \pm 31$ & $635 \pm 43$ & $3035 \pm 568$ & $5694 \pm 4295$ \\
$\mathrm{Cr}[\mathrm{mg} / \mathrm{kg} \mathrm{DM}]$ & $118 \pm 48$ & $436 \pm 77$ & $252 \pm 129$ & $223 \pm 29$ & $201 \pm 50$ & $253 \pm 191$ \\
$\mathrm{Ni}[\mathrm{mg} / \mathrm{kg} \mathrm{DM}]$ & $63 \pm 27$ & $160 \pm 127$ & $90 \pm 4$ & $63 \pm 5$ & $304 \pm 57$ & $579 \pm 419$ \\
$\mathrm{Mo}[\mathrm{mg} / \mathrm{kg} \mathrm{DM}]$ & $27 \pm 10$ & $125 \pm 13$ & $69 \pm 41$ & $43 \pm 13$ & $136 \pm 82$ & $57 \pm 42$ \\
$\mathrm{Co}[\mathrm{mg} / \mathrm{kg} \mathrm{DM}]$ & $17 \pm 7$ & $8 \pm 3$ & $7 \pm 2$ & $20 \pm 3$ & $37 \pm 15$ & $46 \pm 23$ \\
$\mathrm{As}[\mathrm{mg} / \mathrm{kg} \mathrm{DM}]$ & $0.24 \pm 0.07$ & $13.84 \pm 11.47$ & $2.00 \pm 0.42$ & $0.56 \pm 0.33$ & $6.07 \pm 2.86$ & $1.51 \pm 1.84$ \\
$\mathrm{Sb}[\mathrm{mg} / \mathrm{kg} \mathrm{DM}]$ & $1.16 \pm 0.32$ & $8.09 \pm 5.90$ & $2.19 \pm 0.90$ & $4.09 \pm 1.73$ & $3.94 \pm 0.10$ & $2.06 \pm 1.58$ \\
$\mathrm{Se}[\mathrm{mg} / \mathrm{kg} \mathrm{DM}]$ & $0.10 \pm 0.00$ & $0.16 \pm 0.03$ & $0.21 \pm 0.08$ & $0.27 \pm 0.18$ & $0.22 \pm 0.12$ & $0.26 \pm 0.22$ \\
$\mathrm{Fe}[\%]$ & $14.1 \pm 1.0$ & $17.7 \pm 1.9$ & $6.9 \pm 3.1$ & $12.9 \pm 0.2$ & $38.9 \pm 3.4$ & $49.3 \pm 28.0$ \\
$\mathrm{Mn}[\%]$ & $3.38 \pm 0.57$ & $0.12 \pm 0.06$ & $0.06 \pm 0.00$ & $0.07 \pm 0.01$ & $7.44 \pm 3.01$ & $0.35 \pm 0.16$ \\
$\mathrm{Ca}[\%]$ & $6.54 \pm 2.11$ & $0.44 \pm 0.23$ & $0.38 \pm 0.33$ & $0.10 \pm 0.02$ & $2.05 \pm 0.13$ & $0.69 \pm 0.51$ \\
$\mathrm{Mg}[\%]$ & $1.61 \pm 1.00$ & $1.24 \pm 0.58$ & $0.60 \pm 0.04$ & $0.74 \pm 0.09$ & $2.86 \pm 2.02$ & $3.48 \pm 1.62$ \\
$\mathrm{~K} \mathrm{[ \% ]}$ & $0.17 \pm 0.06$ & $3.44 \pm 0.35$ & $1.73 \pm 0.89$ & $1.81 \pm 0.87$ & $3.15 \pm 0.20$ & $1.27 \pm 0.60$ \\
$\mathrm{Na}[\%]$ & $0.05 \pm 0.01$ & $6.01 \pm 3.24$ & $1.44 \pm 0.23$ & $4.46 \pm 2.40$ & $5.59 \pm 3.29$ & $1.26 \pm 0.96$ \\
\hline
\end{tabular}


Table 3 The characteristic of leachate from the tested waste, and classification based on limit values for the acceptance of landfilled wastes in Poland and the obtained values for tested waste $($ mean \pm SD)

\begin{tabular}{|c|c|c|c|c|c|c|c|c|c|}
\hline \multirow{2}{*}{$\begin{array}{l}\text { Parameter } \\
{[\mathrm{mg} / \mathrm{kg} \mathrm{DM}]}\end{array}$} & \multicolumn{3}{|c|}{ Classification of waste $^{\mathrm{a}}$} & \multirow{2}{*}{$\begin{array}{l}\text { Landfilled waste } \\
\text { samples } \\
\text { LFW }\end{array}$} & \multicolumn{5}{|l|}{ Dust samples } \\
\hline & (1) & (2) & (3) & & SGD & $\mathrm{RD}$ & TD & EAFD & PBCD \\
\hline As & 0.5 & 2 & 25 & $0.03( \pm 0.00)$ & $0.24( \pm 0.10)$ & $0.05( \pm 0.01)$ & $0.10( \pm 0.08)$ & $0.06( \pm 0.02)$ & $0.05( \pm 0.05)$ \\
\hline $\mathrm{Cd}$ & 0.04 & 1 & 5 & $<0.05$ & $0.53( \pm 0.53)$ & $0.05( \pm 0.01)$ & $0.10( \pm 0.01)$ & $0.17( \pm 0.06)$ & $0.12( \pm 0.11)$ \\
\hline $\mathrm{Cr}$ & 0.5 & 10 & 70 & $0.3( \pm 0.1)$ & $0.9( \pm 0.7)$ & $0.7( \pm 0.5)$ & $0.4( \pm 0.1)$ & $0.7( \pm 0.2)$ & $0.5( \pm 0.4)$ \\
\hline $\mathrm{Cu}$ & 2 & 50 & 100 & $0.6( \pm 0.1)$ & $7.4( \pm 1.7)$ & $5.7( \pm 1.5)$ & $2.4( \pm 1.6)$ & $2.9( \pm 0.6)$ & $1.0( \pm 0.7)$ \\
\hline Мo & 0.5 & 10 & 30 & $1.5( \pm 0.1)$ & $0.9( \pm 0.1)$ & $0.8( \pm 0.1)$ & $0.6( \pm 0.1)$ & $0.6( \pm 0.1)$ & $0.5( \pm 0.1)$ \\
\hline $\mathrm{Ni}$ & 0.4 & 10 & 40 & $0.2( \pm 0.1)$ & $0.6( \pm 0.3)$ & $0.4( \pm 0.2)$ & $0.2( \pm 0.0)$ & $0.6( \pm 0.1)$ & $0.5( \pm 0.3)$ \\
\hline $\mathrm{Pb}$ & 0.5 & 10 & 50 & $<0.5$ & $5.6( \pm 5.6)$ & $3.1( \pm 2.7)$ & $6.8( \pm 5.7)$ & $14.2( \pm 1.7)$ & $2.0( \pm 1.2)$ \\
\hline $\mathrm{Sb}$ & 0.06 & 0.7 & 5 & $<0.1$ & $<0.1$ & $<0.1$ & $<0.1$ & $<0.1$ & $<0.1$ \\
\hline $\mathrm{Se}$ & 0.1 & 0.5 & 7 & $<0.01$ & $0.07( \pm 0.06)$ & $<0.01$ & $0.07( \pm 0.01)$ & $0.08( \pm 0.07)$ & $0.02( \pm 0.03)$ \\
\hline $\mathrm{Zn}$ & 4 & 50 & 200 & $0.5( \pm 0.1)$ & $1.3( \pm 0.2)$ & $0.8( \pm 0.2)$ & $0.6( \pm 0.1)$ & $2.2( \pm 1.2)$ & $1.2( \pm 0.8)$ \\
\hline $\mathrm{Cl}^{-}$ & 800 & 1500 & 25.000 & $396( \pm 168)$ & $242( \pm 85)$ & $242( \pm 169)$ & $146( \pm 85)$ & $1397( \pm 234)$ & $10( \pm 0)$ \\
\hline $\mathrm{F}^{-}$ & 10 & 150 & 500 & $4.9( \pm 1.4)$ & $7.6( \pm 1.1)$ & $8.5( \pm 0.2)$ & $8.2( \pm 0.3)$ & $8.6( \pm 0.1)$ & $4.1( \pm 1.6)$ \\
\hline $\mathrm{SO}_{4}{ }^{2-}$ & 1000 & 20.000 & 50.000 & $349( \pm 164)$ & $12434( \pm 2102)$ & $7855( \pm 1052)$ & $6266( \pm 1306)$ & $7715( \pm 1921)$ & $143( \pm 62)$ \\
\hline Phenol & 1 & n.r. & n.r. & $1.8( \pm 0.4)$ & $26.7( \pm 3.9)$ & $20.1( \pm 2.8)$ & $11.2( \pm 0.5)$ & $1.4( \pm 0.2)$ & $1.3( \pm 0.3)$ \\
\hline Co & n.r. & n.r. & n.r. & $0.2 \pm 0.0$ & $0.5( \pm 0.3)$ & $0.8( \pm 0.1)$ & $0.5( \pm 0.1)$ & $0.4( \pm 0.1)$ & $<0.2$ \\
\hline $\mathrm{Fe}$ & n.r. & n.r. & n.r. & $0.5 \pm 0.0$ & $4.3( \pm 0.7)$ & $3.2( \pm 0.7)$ & $1.0( \pm 0.5)$ & $2.3( \pm 1.8)$ & $0.6( \pm 0.2)$ \\
\hline $\mathrm{Mn}$ & n.r. & n.r. & n.r. & $0.6 \pm 0.1$ & $3.0( \pm 2.7)$ & $1.4( \pm 1.0)$ & $0.5( \pm 0.0)$ & $6.1( \pm 1.6)$ & $0.8( \pm 0.2)$ \\
\hline $\mathrm{Mg}$ & n.r. & n.r. & n.r. & $5 \pm 2$ & $5( \pm 4)$ & $4( \pm 3)$ & $7( \pm 1)$ & $3( \pm 1)$ & $2( \pm 2)$ \\
\hline $\mathrm{Ca}$ & n.r. & n.r. & n.r. & $4 \pm 2$ & $6( \pm 3)$ & $4( \pm 0)$ & $3( \pm 0)$ & $45( \pm 2)$ & $7( \pm 3)$ \\
\hline $\mathrm{K}$ & n.r. & n.r. & n.r. & $70 \pm 17$ & $257( \pm 205)$ & $226( \pm 174)$ & $490( \pm 461)$ & $720( \pm 29)$ & $45( \pm 19)$ \\
\hline $\mathrm{Na}$ & n.r. & n.r. & n.r. & $358 \pm 99$ & $430( \pm 37)$ & $515( \pm 296)$ & $543( \pm 17)$ & $3343( \pm 938)$ & $193( \pm 192)$ \\
\hline $\mathrm{NH}_{4}^{+}$ & n.r. & n.r. & n.r. & $3 \pm 3$ & $147( \pm 91)$ & $201( \pm 159)$ & $64( \pm 13)$ & $57( \pm 25)$ & $1( \pm 1)$ \\
\hline Formaldehyde & n.r. & n.r. & n.r. & $35.8 \pm 12.7$ & $118.7( \pm 4.1)$ & $83.5( \pm 5.1)$ & $68.9( \pm 6.4)$ & $41.1( \pm 2.4)$ & $29.2( \pm 8.6)$ \\
\hline $\mathrm{CN}^{-}$ & n.r. & n.r. & n.r. & $0.02 \pm 0.00$ & $0.06( \pm 0.04)$ & $0.10( \pm 0.04)$ & $0.09( \pm 0.08)$ & $0.14( \pm 0.13)$ & $0.05( \pm 0.04)$ \\
\hline $\mathrm{pH}$ & n.r. & n.r. & n.r. & $7.7 \pm 0.2$ & $5.1( \pm 0.1)$ & $5.4( \pm 0.5)$ & $6.0( \pm 0.2)$ & $7.6( \pm 1.5)$ & $8.2( \pm 0.5)$ \\
\hline $\mathrm{EC}[\mathrm{uS} / \mathrm{cm}]$ & n.r. & n.r. & n.r. & $106 \pm 29$ & $1820( \pm 113)$ & $1243( \pm 156)$ & $1090( \pm 139)$ & $1768( \pm 223)$ & $43( \pm 16)$ \\
\hline
\end{tabular}

n.r. not required

a(1) inert, (2) non-hazardous, (3) hazardous waste (Journal of Law 2015)

on the species. Wang and Song (2019) found that low salinity $(0.5 \% \mathrm{NaCl}$ in soil solution) can reduce oxidative stress due to heavy metals in halophytes by increasing the levels of antioxidant enzyme activity. While Hoekstra et al. (2002) found that the salinity effects of leachate are not significant for plant germination at $\mathrm{EC}<2000 \mu \mathrm{S} / \mathrm{cm}$. The leachates from dust samples were characterized by a higher degree of salinity than the leachates from LFW, but they did not exceed the phytotoxic value. LFW leachate was characterized by a low EC value and thus low salinity. According to Polish law, the salinity of leachate from waste can also be determined on the basis of the sum of the chloride and sulfate concentrations (Journal of Law 2015). The chloride and sulfate concentrations were low in LFW leachate, they were below the inert waste limits. Leachate from the tested dust were characterized by a higher concentration of sulfates than LFW. Dust samples with the highest sulfate concentration were also characterized by a high $\mathrm{EC}$ value. This may indicate that the $\mathrm{EC}$ value of the leachate from the tested waste was primarily affected by sulfates. In contrast to chlorides and sulfates, fluorides are toxic to biota even at low concentrations (Stevens et al. 2000; Palmieri et al. 2014). Fluoride concentration was analyzed in the leachate, as it may be present in foundry waste. Organic binders are the main source of fluorides in foundry waste leachate (http://life-foundrysand.com). The fluoride concentration was low in all tested leachate. Plant resistance to fluoride depends on the plant species. Stevens et al. (1998) report the toxic for plants is fluoride concentration at $50-260 \mu \mathrm{M}(1-5 \mathrm{mg} / \mathrm{L})$ for tomatoes to 2532-13157 $\mu \mathrm{M}(50-250 \mathrm{mg} / \mathrm{L})$ for cabbage. Gupta et al. (2009) found a negative effect of aqueous fluoride extracts 
on rice seeds on germination $>20 \mathrm{mg} / \mathrm{L}$ and root elongation $>30 \mathrm{mg} / \mathrm{L}$, respectively. Although ammonia is not limited in Polish waste leachate, in the current study $\mathrm{NH}_{4}{ }^{+}$content was analyzed, as potential source of eluted pollution. The main sources of ammonia in foundry waste are organic binders (Deng 2004; Siddiquea et al. 2010). It is known that ammonia cause a phytotoxic effect (De la Torre et al. 2000; Tiquia 2000; Hoekstra et al. 2002; Ramírez et al. 2008). In water extract, ammonia may be present in two chemical forms: $\mathrm{NH}_{4}^{+}$and $\mathrm{NH}_{3}$. The concentration of both forms depends on the $\mathrm{pH}$. $\mathrm{NH}_{3}$ has been shown to be more phytotoxic (Hoekstra et al. 2002). $\mathrm{NH}_{3}$ concentration is calculated from the equilibrium equation from $\mathrm{NH}_{4}{ }^{+}$ concentration and $\mathrm{pH}$. According to Bennett and Adams (1970) phytotoxic concentration of ammonia in water extract is $13 \mathrm{mM}(\approx 220 \mathrm{mg} / \mathrm{L})$. Whereas, Dowling (1993) found differences in tolerance to ammonia between plant species, e.g. the tolerance level for chickpeas was $20.8 \mathrm{mM}$ $(\approx 354 \mathrm{mg} / \mathrm{L})$; for maize, wheat, barley, sorghum, panicum and sunflower was $10.2 \mathrm{mM}(\approx 173 \mathrm{mg} / \mathrm{L})$ and for cotton, canola and canary was $5.4 \mathrm{mM}(\approx 92 \mathrm{mg} / \mathrm{L})$. Based on the phytotoxic ammonia concentrations mentioned above, it may be concluded that ammonia concentrations in the leachate from the tested waste should not have a phytotoxic effect on Lepidium sativum. It should be noted here that the values given in Table 3 were converted from units of concentration $\mathrm{mg} / \mathrm{L}$ to $\mathrm{mg} / \mathrm{kg}$ (conversion factor $\sim 10 / 1$ ). No data for the phytotoxicity of ammonia to cress (Lepidium sativum) was found in the literature. The heavy metal concentration in the leachate was low (except EAFD), compared to the total content in the waste. The high concentration of lead in the leachate from EAFD was associated with a high total content of this metal in these dusts, which was confirmed by Škvára et al. (2002) in the analysis of leachate from EAFD. The lowest metal concentrations in the leachate were determined for LFW, which has been confirmed by studies of other authors (Hamilton and Sammes 1999; Škvára et al. 2002; Dungan and Dees 2009; Dayton et al. 2010; Siddiquea et al. 2010; Mymrin et al. 2016). An increased Fe content in the leachate from some dust samples (SGD, RD, EAFD) was found. Although the concentration of this metal is not normalized in waste leachate, it may negatively affect plant growth due to the inhibition of nutrient uptake and competition with other micronutrients (Rout et al. 2015). The concentration of metalloids in most of the leachate was below or within the limit of quantification. It follows that $\mathrm{As}, \mathrm{Sb}$ and $\mathrm{Se}$ in foundry waste were in water insoluble forms. Arsenic, from all metalloids, is the most toxic pollutant (Kabata-Pendias 2010). The toxicity of arsenic is closely dependant on its chemical form. As has a negative impact on the root and shoot length of plants (Seneviratne et al. 2019). In contrast, selenium is a microelement which stimulates germination and plant development (Barrientos et al. 2012; Praveen et al. 2017). Antimony is an element whose influence on biota is not well researched and understood (Kabata-Pendias 2010). Sb toxicity to germination and plant growth depends on the species (Liang et al. 2018). Among the nutrients in leachate, the highest concentration of $\mathrm{Na}$ was determined. The leachate from EAFD was characterized by the highest concentration of all nutrients. Cyanides, phenol and formaldehyde from the residue of organic binders may be present in leachate from foundry waste (Oliva-Teles et al. 2002; Dungan et al. 2006; Siddiquea et al. 2010). These compounds are toxic to biota, therefore its leaching from foundry waste should be monitored (Siddiquea et al. 2010). However, it was found that phenol and formaldehyde from SFS may stimulate microbial activity (Dungan et al. 2006). There is a lack of information in the currently available literature concerning the effects of formaldehyde in aqueous solutions on seed germination and plant growth. In contrast, the influence of cyanide and phenol on plant germination is widely described (Hoekstra et al. 2002; Yu and Gu 2007; Palmieri et al. 2014). Hoekstra et al. (2002) found that cyanides and amines are nitrogen phytotoxic compounds that decrease plant germination. It is known that vascular plants have an enzyme system that detoxifies cyanides by converting them into the asparagine amino acid. For this reason vascular plants are used for the phytoremediation of soils contaminated with cyanides ( $\mathrm{Yu}$ and $\mathrm{Gu}$ 2007). Palmieri et al. (2014) found that cyanides $(0.0031 \mathrm{mg} / \mathrm{L})$ may be less phytotoxic than fluorides $(0.3938 \mathrm{mg} / \mathrm{L})$ in elutes from solid waste from aluminum production (SPL-Spent pot-liner). In the current research, the cyanide content of LFW leachate was low compared to leachate from dust. The highest $\mathrm{CN}^{-}$content was determined in the leachate from EAFD. The phenol content in the leachate from LFW, EAFD and PBCD was slightly higher than the limit value for inert waste. In contrast, the phenol content in leachates from SGD, RD, TD was very high (11.2-26.7 mg/kg DM). The source of phenol in foundry wastes may be phenol-formaldehyde binders which are used in the foundry. The tested leachates were characterized by a high concentration of formaldehyde. The highest formaldehyde content was determined in the leachate from SGD, RD and TD. The main component of these dusts are residues from spent binder and SFS.

In summary, according to the requirements of Polish regulations (Table 3) the LFW samples are classified as non-hazardous waste. The EAFD samples, due to the high concentration of $\mathrm{Pb}$ in the leachate, are classified as hazardous waste, although the concentration of other contaminants was below the requirements for non-hazardous waste. Other dust samples have been classified as non-hazardous waste. 
Fig. 2 Germination index (GI) [\%] of the foundry waste leachates. Error bars indicate standard deviations. The horizontal line represents limits on phytotoxicity/stimulating of root growth and seed germination expressed as GI

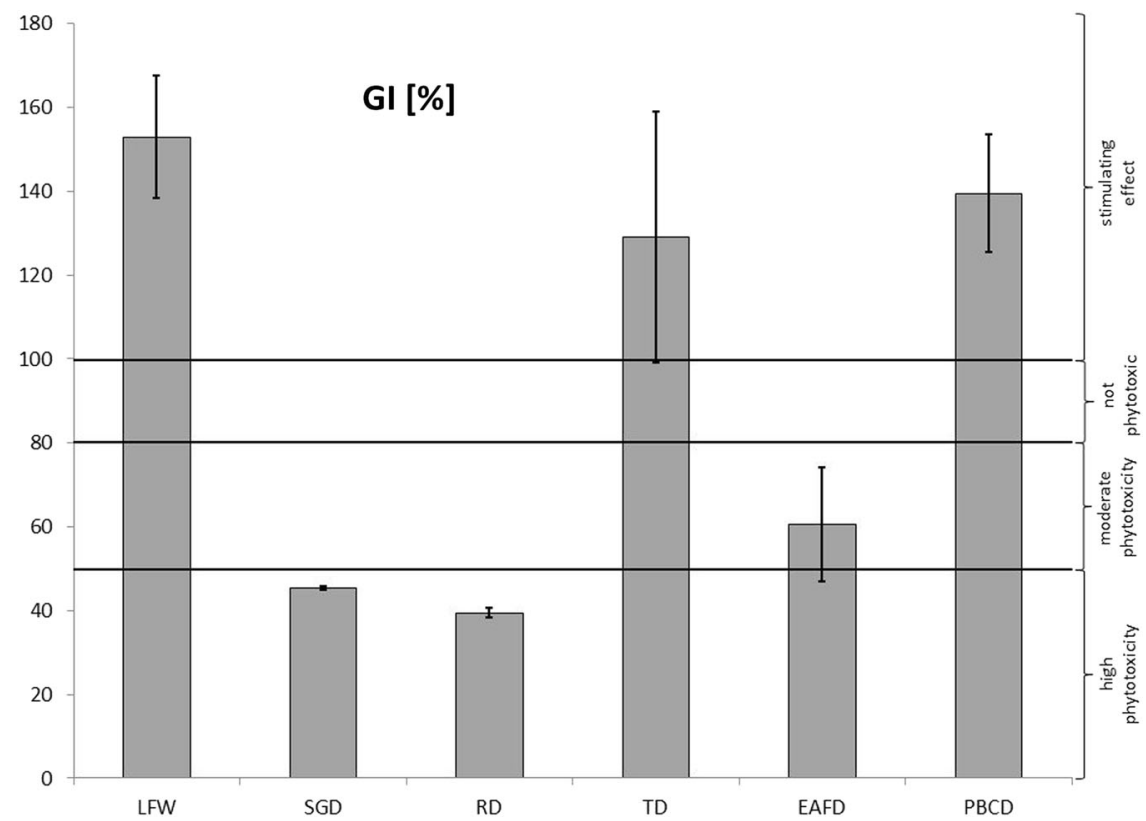

\section{Phytotoxicity tests}

\section{The germination test}

Seed germination rates (RSG) for all waste samples ranged between 90 and $100 \%$. Therefore, RSG was not a sensitive indicator of phytotoxicity, a fact which has been confirmed by other authors (Fuentes et al. 2004; Gyuricza et al. 2010, Mitelut and Popa 2011). Differences were found in root length (elongation) (RRG) which affected the final GI value. The roots are responsible for the absorption of water, nutrients and contaminants, which affects the development of the plant. However, most of the nutrients are taken by the germ from the seeds, so the impact of contaminants on plant development in the first stage of growth may not be apparent (Khan et al. 2018; Seneviratne et al. 2019). During the germination test, different leachate effects were observed on Lepidium sativum seeds. An increased root length was observed for all leachates from LFW compared to the control. In a few cases, the tegument of seeds exposed to leachates from dust turned black (SGD, RD) and also for one sample of EAFD (P4). Leachate from these dust samples were characterized by low $\mathrm{pH}$ and a high concentration of Fe, phenol and formaldehyde (Table 3). A decreased root length was also observed for these seeds. A weak root elongation effect, without any change in tegument color, was also observed for leachate from one sample of EAFD (P14). The leachate from sample P14 was characterized by a high concentration of $\mathrm{Fe}(4 \mathrm{mg} / \mathrm{L})$ and a slightly alkaline $\mathrm{pH}$ (8.6). Therefore, a possible cause of the blackening of the seed tegument may be high iron concentration and the low $\mathrm{pH}$ of the leachate. A similar effect of tegument blackening of Lepidium sativum due to iron in the water extract was obtained in another experiment.

Figure 2 shows the GI values of all samples. GI values indicate the effect of the inhibition or stimulation of seed growth. The assessment was based on Zucconi et al. (1984) guidelines. An increase in root length and GI value compared to the control for LFW leachate was found, which indicates a stimulating effect on seed growth. Low concentrations of heavy metals and other contaminants were determined in leachate from LFW, compared to leachate from dust samples. Heavy metal concentrations were low and could stimulate germination and root growth (Seneviratne et al. 2019).These leachate were also characterized by neutral or slightly alkaline $\mathrm{pH}$ and a low $\mathrm{EC}$ value.

In the case of leachate from foundry dusts, significant differences in the length of Lepidium sativum roots were found. Lower root lengths and GI compared to the control were found for leachate from dust samples: SGD, RD and EAFD. The inhibition effect may depend on the high concentration of metals, and also on the interaction between the metals and other parameters $\left(\mathrm{pH}, \mathrm{EC}, \mathrm{Cl}, \mathrm{SO}_{4}\right.$, formaldehyde, phenol) of the leachate. Increased root growth compared to the control and a high GI value were found for leachate from other dust samples (TD, PBCD), which may indicate the stimulation of plant growth. The leachate from those samples were characterized by a low concentration of pollutants. It is known that many factors can affect root length (elongation) and GI such as unfavorable $\mathrm{pH}$ levels in combination with heavy metals, EC and anions, that may affect leachate phytotoxicity. Phytotoxicity is the result of a combination of several factors, which have inhibitory effects on plant growth. The metals in the leachates can 
have a dual effect, stimulation or inhibition, on the growth of seeds (Phoungthong et al. 2016). Heavy metals can inhibit plant seed germination and root elongation, when their concentrations exceed a certain value (Phoungthong et al. 2018). The $\mathrm{pH}$ value can negatively affect GI and root elongation only in the presence of other factors such as high heavy metal concentration. However, Phoungthong et al. (2016) found a negative influence of the $\mathrm{pH}$ of the leachate on GI only at a pH level which is strongly acidic, $\mathrm{pH}<2$ and a strongly alkaline $\mathrm{pH}, \mathrm{pH}>13$. The authors stated that, the $\mathrm{pH}$ of leachate may be correlated with GI to a degree which is insignificant.

\section{The growing and accumulation test}

Plant appearance, cotyledon staining and plant height were evaluated. Poor coloring may indicate a lack of nutrients $(\mathrm{Mg})$ in the leachate or the effect of heavy metals on chlorophyll. The central $\mathrm{Mg}$ atom of chlorophyll may be substituted by another divalent heavy metal in excess $(\mathrm{Hg}$, $\mathrm{Cu}, \mathrm{Cd}, \mathrm{Ni}, \mathrm{Pb}, \mathrm{Zn}$ ), which contribute to a decline in photosynthesis (Gupta et al. 2013; Seneviratne et al. 2019). In the accumulation test, as in the germination test, it was found that blackening of the tegument of Lepidium sativum occurred while it was grow on the leachate from SGD, RD and one sample of EAFD (No. P4). For these leachates, reduced Lepidium sativum sprout growth compared to the control and poor colouration of cotyledon were found. The reduced plant growth may be an effect of the high concentration of phenol, formaldehyde, ammonia and sulfates as well as the high EC value of those leachates. Lepidium sativum grew on the most of tested leachate, they were in good condition and characterized by well-colored (intensely green) cotyledons. The length of the tested plants (Lepidium sativum) growing on waste leachate, measured from the end of the roots to the cotyledon, ranged from 90 to $120 \mathrm{~mm}$, with the exception of Lepidium sativum from SGD and RD leachate, which was only $7-13 \mathrm{~mm}$ in length. The average length of Lepidium sativum from the control was $120 \mathrm{~mm}$.

The total metal, metalloids and nutrients content in the Lepidium sativum is shown in Fig. 3. Among the metals analysed, the content of $\mathrm{Fe}$ and $\mathrm{Mn}$ was highest in the plants, which was due to the high concentration of these metals in the leachates. Among the other metals, the lowest content for $\mathrm{Cd}$, Co, Mo and metalloids in Lepidium sativum was determined. The content of $\mathrm{Cd}, \mathrm{Ni}, \mathrm{Mo}, \mathrm{Cr}, \mathrm{Co}$ in Lepidium sativum from the control and LFW leachates was within or below LOQ. Plants (Lepidium sativum) growing on leachate with SGD and RD were characterized by the highest content of most metals, except $\mathrm{Pb}$, compared to the control and other leachates. No high content of $\mathrm{Pb}$ in Lepidium sativum growing on leachate with EAFD was found, despite the high concentration of $\mathrm{Pb}$ in leachate from these dusts. In the case of RD and TD dusts, the $\mathrm{Pb}$ content in leachates differed significantly for the sample collected during the first and second terms. Similar differences which were found in the $\mathrm{Pb}$ content in Lepidium sativum, may indicate that the plants tested assimilated this metal from the leachate. Of the nutrients analysed, calcium and potassium from leachate were accumulated to the highest degree by most plants. Magnesium content in Lepidium sativum was slightly lower than $\mathrm{Ca}$ and $\mathrm{K}$. Magnesium is the basic nutrient in the process of photosynthesis, as a component of chlorophyll, however, at the initial phase of growth (seedlings) photosynthesis is not intensive in plants. The accumulation of $\mathrm{Na}$ in the plants was low, despite its high concentration in the leachates.

In summary, in the discussion of accumulation by Lepidium sativum, it may be stated that the excess of a metal and metalloids in leachate was not directly related to its accumulation in plants. In the current research it the impact of other parameters affecting the accumulation of metals or metalloids by Lepidium sativum should be considered, not only the content of the leachate. It has been established that, heavy metals can be absorbed by plants passively (e.g. osmosis) or actively. Absorption is regulated by many factors, and plants have mechanisms that block the excessive absorption of metals from the substrate. Therefore, the content of metals in leachate is not necessarily correlated with its accumulation by plants.

\section{Correlations analysis}

The simple correlation between the content of heavy metals, metalloids and nutrients in plants and its concentration in the leachate and between GI and leachate variables were calculated (Table 4). A positive correlation means that both variables (element in the plant and element in the leachate) vary in the same way. A negative correlation implies that the relationship between the variables is the opposite, hence, when one increases the other decreases. In the correlation calculations, the limit value was used for the values below the limit of quantification. It was found that $\mathrm{Fe}(r=0.871)$, Mn $(r=0.744)$, As $(r=0.893)$ and Se $(r=0.848)$ in plants was significantly correlated with concentrations in leachate. Lower correlation coefficients between for $\mathrm{Cu}, \mathrm{Cr}$ and $\mathrm{Co}$ concentration in leachate and its content in Lepidium sativum were obtained.

Negative correlation between $\mathrm{Cu}, \mathrm{Co}, \mathrm{Fe}, \mathrm{Mn}$ and GI concentration was found. While, for $\mathrm{Pb}, \mathrm{Cr}, \mathrm{K}, \mathrm{Na}$ and $\mathrm{GI}$ a low correlation coefficient was determined. Correlation coefficients between other metals, metalloids and nutrients and GI were not statistically significant. Negative correlations between metals and metalloids in leachate and GI was also found by other authors (García-Lorenzo et al. 2014; Phoungthong et al. 2016, 2018). A positive correlation was 

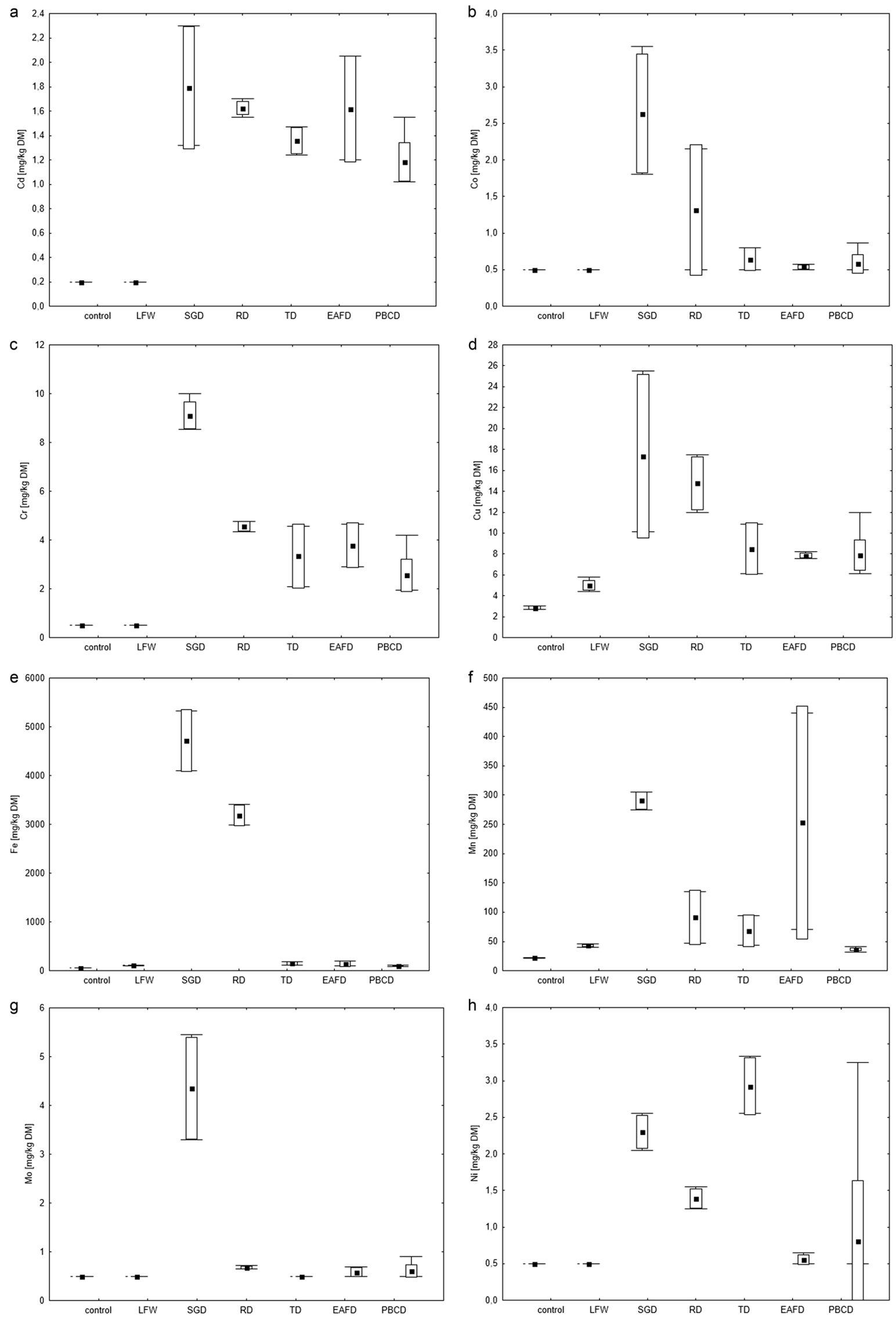

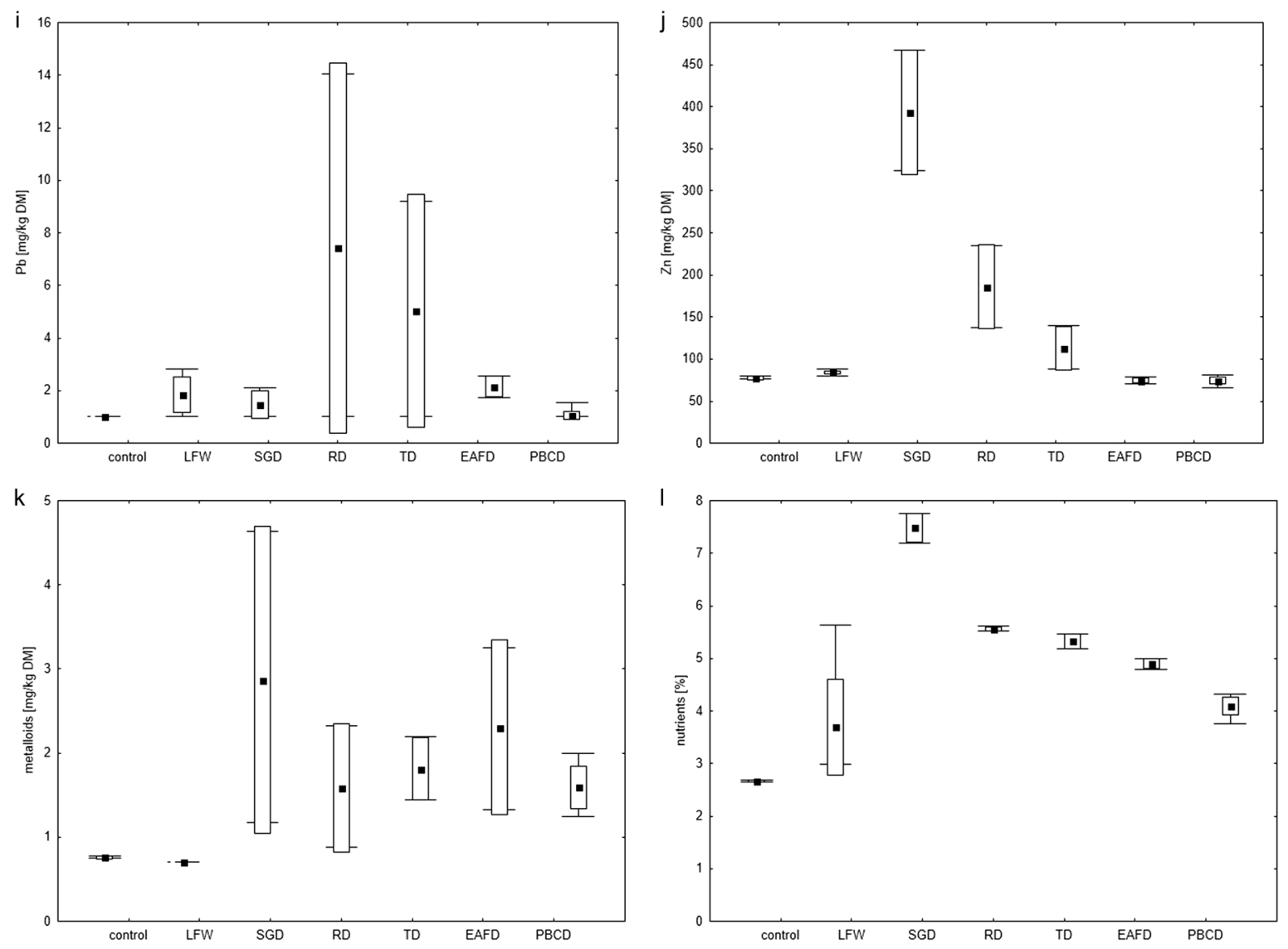

Fig. 3 Box and whisker plots of heavy metals, metalloids and nutrients accumulated by Lepidium sativum after 7 days test, compared to control: a Cd, b $\mathrm{Co}, \mathbf{c} \mathrm{Cr}$, d Cu, e Fe, f Mn, g Mo, h Ni, i Pb, j Zn, k

found between $\mathrm{pH}$ and GI for Lepidium sativum, suggesting that low pH value may be phytotoxic (García-Lorenzo et al. 2014; Phoungthong et al. 2016). In addition, the GI was negatively correlated with $\mathrm{EC}$, which confirms that the increase salinity of leachate may negatively affects germination and root growth (García-Lorenzo et al. 2014; Phoungthong et al. 2016). Similarly to the EC, a negative correlation between sulfate, fluoride, ammonia, phenol and formaldehyde concentration in leachate and GI was found.

\section{Conclusions}

LFW were characterized by a low total content of heavy metals and metalloids compared to dusts. EAFD was characterized by the highest content of $\mathrm{Pb}, \mathrm{Cd}, \mathrm{Mo}, \mathrm{Mn}, \mathrm{Zn}$ and $\mathrm{Cu}$. Among the heavy metals, iron was the dominant component in all the tested waste samples. Among the metalloids, the highest content of $\mathrm{Sb}$, followed by As was found in the tested waste. The Se content was the lowest of the metalloids. The content of nutrients $(\mathrm{Ca}, \mathrm{Mg}, \mathrm{K}, \mathrm{Na})$ in the tested waste varied within wide limits. The leachates

the sum of metalloids, $\mathbf{l}$ the sum of nutrients. The edges of the boxes show the SD, the whiskers show min-max, respectively. The mean is marked with a square point

from the tested waste were characterized by a wide $\mathrm{pH}$ range and salinity (EC). The highest concentration of pollutants in leachate from dust: SGD and RD were determined. These dust samples were collected from shock grating and installation of regeneration SFS dust collectors, and mainly consisted of residues of SFS and organic binders, which could be affected by high salinity, phenol and formaldehyde leachate from this waste. Leachate from LFW contained a lower concentration of pollutants than leachate from dust samples. According to the requirements of Polish regulations the tested waste samples were classified as: non-hazardous (LFW, SGD, RD, TD, PBCD) and hazardous waste (EAFD) due to high $\mathrm{Pb}$ concentration in leachate.

Higher GI values were found for LFW, TD, PBCD leachates compared to the control, which may suggest a stimulating effect of those leachate to Lepidium sativum root growth. Leachate from EAFD were characterized by a moderate phytotoxicity. In contrast, leachate from SGD and RD had phytotoxic effects on the germination and root growth of Lepidium sativum. The leachate from these dusts (SGD, RD) were characterized by low $\mathrm{pH}$ values, and high 


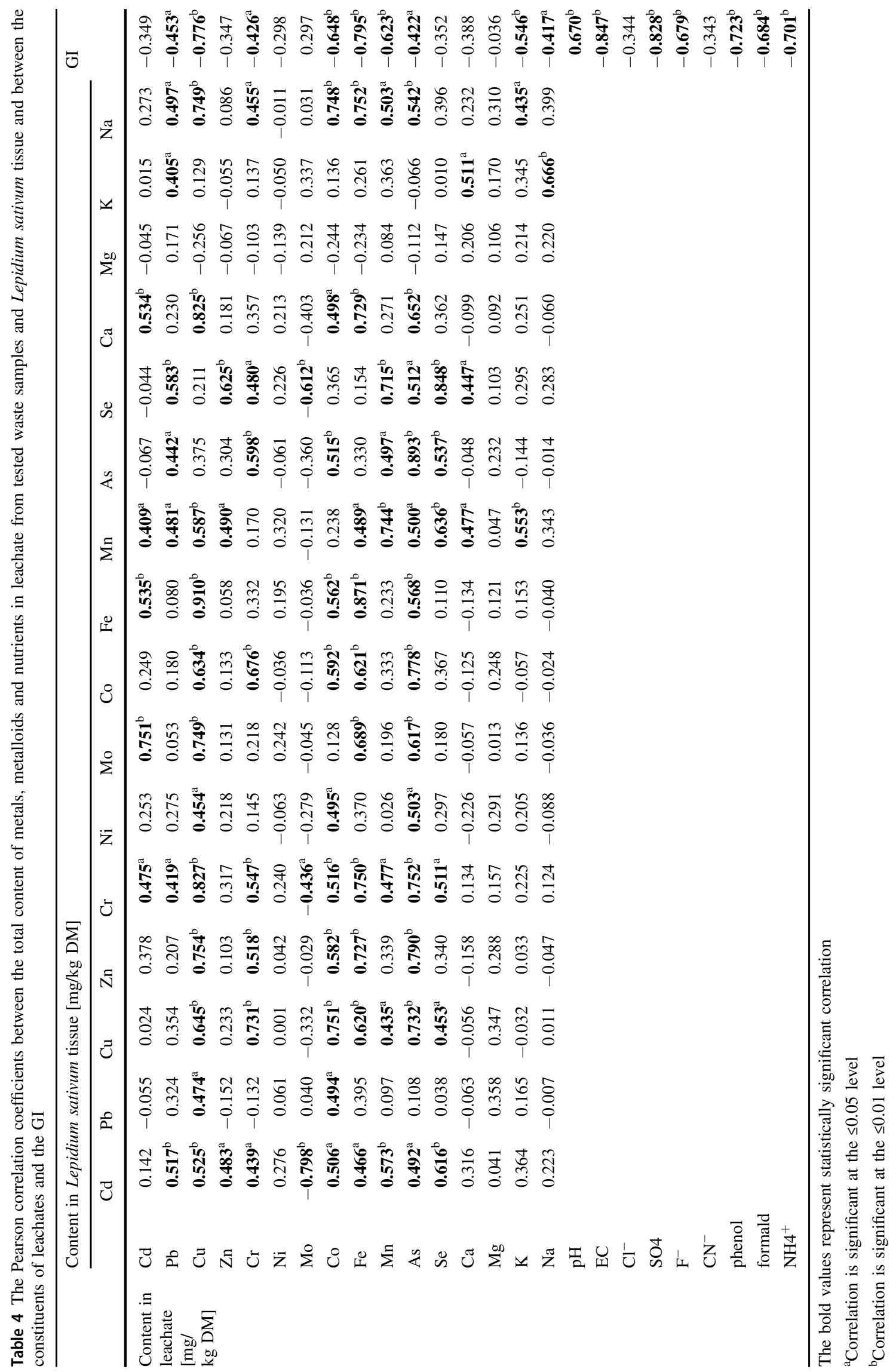


concentration of $\mathrm{Cu}, \mathrm{Fe}$, sulfates, phenol, formaldehyde and ammonia, compared to other leachates, which could have the effect of reducing GI value. For these leachates, a reduction in plant length and the poor coloration of cotyledon compared to the control along with a blackening of the tegument was also found, this may indicate the influence of one or more leachate components on these phenomena. In addition, the blackening of tegument phenomenon was also found for one sample of EAFD dust, which was characterized by low $\mathrm{pH}$ and an increased $\mathrm{Fe}$ content in the leachate. This effect was not observed for the second EAFD sample, which was alkaline $(\mathrm{pH}=8.6)$. For this reason, it was stated that both of these factors, i.e. high $\mathrm{Fe}$ concentration and low $\mathrm{pH}$, may affect the blackening of tegument. Current studies have concluded that the excess of a metal and metalloids in the leachate was not directly related to its accumulation in plants. One example was the low $\mathrm{Pb}$ content of Lepidium sativum growing on leachate from EAFD contaminated with this metal. Based on the correlation analysis, it was found that the plants may accumulate metals such as Fe, Mn, As and Se from leachate. For other components lower statistically significant correlation was calculated. In terms of the relationship between GI and parameters of the leachate it was found that $\mathrm{EC}, \mathrm{Cu}, \mathrm{Co}, \mathrm{Fe}$, $\mathrm{Mn}, \mathrm{Pb}, \mathrm{Cr}, \mathrm{K}, \mathrm{Na}$, sulfate, fluoride, ammonia, phenol and formaldehyde concentration were negatively correlated and $\mathrm{pH}$ positively correlated. In summary, in order to assess the accumulation of elements by plants the impact of many parameters should be considered, and not only the content in the leachate. The plant may inhibit the absorption of pollutants from the substrate through the activation of absorption blocking mechanisms.

Acknowledgements The author acknowledge Opole University of Technology for funding this research work and foundry management for cooperation and Management Systems Office of the foundry for providing the dust samples.

\section{Compliance with ethical standards}

Conflict of interest The author declares no conflict of interest.

Publisher's note Springer Nature remains neutral with regard to jurisdictional claims in published maps and institutional affiliations.

Open Access This article is licensed under a Creative Commons Attribution 4.0 International License, which permits use, sharing, adaptation, distribution and reproduction in any medium or format, as long as you give appropriate credit to the original author(s) and the source, provide a link to the Creative Commons license, and indicate if changes were made. The images or other third party material in this article are included in the article's Creative Commons license, unless indicated otherwise in a credit line to the material. If material is not included in the article's Creative Commons license and your intended use is not permitted by statutory regulation or exceeds the permitted use, you will need to obtain permission directly from the copyright holder. To view a copy of this license, visit http://creativecommons. org/licenses/by/4.0/.

\section{References}

Alonso-Blázquez N, García-Gómez C, Fernández MD (2015) Influence of $\mathrm{Zn}$-contaminated soils in the antioxidative defence system of wheat (Triticum aestivum) and maize (Zea mays) at different exposure times: potential use as biomarkers. Ecotoxicology 24 (2):279-291. https://doi.org/10.1007/s10646-014-1376-6

Andrés A, Ortíz I, Viguri JR, Irabien A (1995) Long-term behaviour of toxic metals in stabilized steel foundry dusts. J Hazard Mater 40(1):31-42. https://doi.org/10.1016/0304-3894(94)00078-U

Baran A, Czech T, Wieczorek J (2014) Chemical properties and toxicity of soils contaminated by mining activity. Ecotoxicology 23(7):1234-1244. https://doi.org/10.1007/s10646-014-1266-y

Baran A, Tarnawski M (2015) Assessment of heavy metals mobility and toxicity in contaminated sediments by sequential extraction and a battery of bioassays. Ecotoxicology 24(6):1279-1293. https://doi.org/10.1007/s10646-015-1499-4

Barrientos EY, Flores CR, Wrobel K, Wrobel K (2012) Impact of cadmium and selenium exposure on trace elements, fatty acids and oxidative stress in Lepidium sativum. J Mexican Chem Soc 56(1):3-9. https://doi.org/10.29356/jmcsv56i1267

Baumgarten A, Spiegel H (2004) Phytotoxicity (Plant tolerance), HORIZONTAL - 8. Agency for Health and Food Safety, Vienna, Available online http://www.ecn.nl/docs/society/horizontal/hor8_ phytotoxicity.pdf

Bennett AC, Adams F (1970) Concentration of NH3(aq) Required for incipient NH3 toxicity to seedlings. Soil Sci Soc Am J 34(2):259. https://doi.org/10.2136/sssaj197003615995003400020024x

Bożym M (2017) The study of heavy metals leaching from waste foundry sands using a one-step extraction E3S. Web of Conferences, 19. https://doi.org/10.1051/e3sconf/20171902018

Bożym M (2018) Alternative directions for the use of foundry waste, especially for energy management. Sci Noteb Inst Miner Raw Mater Energy Manag Pol Acad Sci 105:197-212

Bożym M (2019) Assessment of leaching of heavy metals from landfilled foundry waste during exploitation of the heaps. Pol J Environ Studies 28(6):4117-4126. https://doi.org/10.15244/pjoes/99240

Bożym M, Dąbrowska I (2012) Directions of foundry waste management. In: Oszanca K (ed). Problems in environmental protection in the Opole Voivodeship-waste and sewage, Atmoterm 24-41

Bożym M, Staszak D, Majcherczyk T (2009) The influence of waste products from steel foundry dump on heavy metals and radionuclides contaminations in local soils. Prace ICiMB 4:107-122

Curieses SP, Sáenz ME, Larramendy M, Di Marzio W (2016) Ecotoxicological evaluation of foundry sands and cosmetic sludges using new earthworm biomarkers. Ecotoxicology 25(5):914-923. https://doi.org/10.1007/s10646-016-1649-3

Dallinger R, Lagg B, Egg M, Schipflinger R, Chabicovsky M (2004) $\mathrm{Cd}$ accumulation and $\mathrm{Cd}$-metallothionein as a biomarker in Cepaea hortensis (Helicidae, Pulmonata) from laboratory exposure and metal-polluted habitats. Ecotoxicology 13(8):757-772. https://doi.org/10.1007/s10646-003-4474-4

Dayton EA, Whitacre SD, Dungan RS, Basta NT (2010) Characterization of physical and chemical properties of spent foundry sands pertinent to beneficial use in manufactured soils. Plant Soil 329(1):27-33. https://doi.org/10.1007/s11104-009-0120-0

De la Torre AI, Jiménez JA, Carballo M, Fernandez C, Roset J, Muoz MJ (2000) Ecotoxicological evaluation of pig slurry. Chemosphere 41(10):1629-1635. https://doi.org/10.1016/S0045-6535 (00)00038-2 
Deng A (2004) Excess foundry sand characterization and experimental investigation in controlled low-strength material. ProQuest Dissertations and Theses. p 447

Dowling CW (1993) Tolerance of ten crop species to atmospheric ammonia during seed germination, radicle and coleoptile growth. In Plant Nutrition-from Genetic Engineering to Field Practice Springer, Netherlands, pp 541-544. https://doi.org/10.1007/97894-011-1880-4_116

Dungan RS, Dees NH (2009) The characterization of total and leachable metals in foundry molding sands. J Environ Manag 90 (1):539-548. https://doi.org/10.1016/jjenvman200712004

Dungan RS, Kukier U, Lee B (2006) Blending foundry sands with soil: Effect on dehydrogenase activity. Sci Total Environ 357 (1-3):221-230. https://doi.org/10.1016/jscitotenv200504032

Fuentes A, Lloréns M, Sáez J, Aguilar MI, Ortuño JF, Meseguer VF (2004) Phytotoxicity and heavy metals speciation of stabilised sewage sludges. J Hazard Mater 108(3):161-169. https://doi.org/ 10.1016/jjhazmat200402014

García-Gómez C, Esteban E, Sánchez-Pardo B, Fernández MD (2014a) Assessing the ecotoxicological effects of long-term contaminated mine soils on plants and earthworms: relevance of soil (total and available) and body concentrations. Ecotoxicology 23(7):1195-1209. https://doi.org/10.1007/s10646-014$1262-2$

García-Gómez C, Sánchez-Pardo B, Esteban E, Peñalosa JM, Fernández MD (2014b) Risk assessment of an abandoned pyrite mine in Spain based on direct toxicity assays. Sci Total Environ 470-471C:390-399. https://doi.org/10.1016/jscitotenv201309101

García-Lorenzo ML, Martínez-Sánchez MJ, Pérez-Sirvent C, Molina $\mathrm{J}$ (2009) Ecotoxicological evaluation for the screening of areas polluted by mining activities. Ecotoxicology 18(8):1077-1086. https://doi.org/10.1007/s10646-009-0362-x

García-Lorenzo ML, Martínez-Sánchez MJ, Pérez-Sirvent C (2014) Application of a plant bioassay for the evaluation of ecotoxicological risks of heavy metals in sediments affected by mining activities. J Soils Sediments 14:1753-1765. https://doi.org/10. 1007/s11368-014-0942-0

Gupta S, Banerjee S, Mondal S (2009) Phytotoxicity of fluoride in the germination of paddy (Oryza sativa) and its effect on the physiology and biochemistry of germinated seedlings. Fluoride 42 (2): $142-146$

Gupta DK, Huang HG, Nicoloso FT, Schetinger MR, Farias JG, Li TQ, Razafindrabe BHN, Aryal N, Inouhe M (2013) Effect of Hg, As and $\mathrm{Pb}$ on biomass production, photosynthetic rate, nutrients uptake and phytochelatin induction in Pfaffia glomerata. Ecotoxicology 22(9):1403-1412. https://doi.org/10.1007/s10646013-1126-1

Gyuricza V, Fodor F, Szigeti Z (2010) Phytotoxic effects of heavy metal contaminated soil reveal limitations of extract-based ecotoxicological tests. Water Air Soil Pollut 210(1-4):113-122. https://doi.org/10.1007/s11270-009-0228-0

Hamilton IW, Sammes NM (1999) Encapsulation of steel foundry bag house dusts in cement mortar. Cem Concr Res 29(1):55-61. https://doi.org/10.1016/S0008-8846(98)00169-0

Hoekstra NJ, Bosker T, Lantinga EA (2002) Effects of cattle dung from farms with different feeding strategies on germination and initial root growth of cress (Lepidium sativum L). Agric Ecosyst Environ 93(1-3):189-196. https://doi.org/10.1016/S0167-8809 (01)00348-6

$\mathrm{Hu}$ Z, Xie Y, Jin G, Fu J, Li H (2015) Growth responses of two tall fescue cultivars to $\mathrm{Pb}$ stress and their metal accumulation characteristics. Ecotoxicology 24(3):563-572. https://doi.org/10.1007/ s10646-014-1404-6

Kabata-Pendias A (2010) Trace elements in soils and plants: Fourth edition In Trace Elements in Soils and Plants, Fourth Edition CRC Press. https://doi.org/10.1201/b10158
Khan AH, Libby M, Winnick D, Palmer J, Sumarah M, Ray MB, Macfie SM (2018) Uptake and phytotoxic effect of benzalkonium chlorides in Lepidium sativum and Lactuca sativa. J Environ Manag 206:490-497. https://doi.org/10.1016/jjenvman201710077

Liang SX, Gao N, Li X, Xi X (2018) Toxic effects of antimony on the seed germination and seedlings accumulation in Raphanus sativus L radish and Brassica napus L. Mol Biol Rep 45(6):2609-2614. https://doi.org/10.1007/s11033-018-4430-2

Lilja R, Liukkonen S (2008) Industrial hazardous wastes in Finland trends related to the waste prevention goal. J Clean Prod 16 (3):343-349. https://doi.org/10.1016/jjclepro200608015

Liu D, Zou J, Meng Q, Zou J, Jiang W (2009) Uptake and accumulation and oxidative stress in garlic (Allium sativum L) under lead phytotoxicity. Ecotoxicology 18(1):134-143. https://doi.org/10. 1007/s10646-008-0266-1

Mañas P, De las Heras J (2018) Phytotoxicity test applied to sewage sludge using Lactuca sativa $L$ and Lepidium sativum $L$ seeds. Int J Environ Sci Technol 15(2):273-280. https://doi.org/10.1007/ s13762-017-386-z

Mitelut AAC, Popa ME (2011) Seed germination bioassay for toxicity evaluation of different composting biodegradable materials. Romanian Biotechnol Lett 16(1 Suppl):121-129

Mymrin V, Nagalli A, Catai RE, Izzo RLS, Rose J, Romano CA (2016) Structure formation processes of composites on the base of hazardous electric arc furnace dust for production of environmentally clean ceramics. J Clean Prod 137:888-894. https:// doi.org/10.1016/jjclepro201607105

OECD (2006) OECD Test Guideline 208: Terrestrial plant testseedling emergence and seedling growth test guidelines for the testing of chemicals, terrestrial plant test seedling emergence and seedling growth test. https://doi.org/10.1787/9789264070066-en

Oliva-Teles MT, Paíga P, Delerue-Matos CM, Alvim-Ferraz MCM (2002) Determination of free formaldehyde in foundry resins as its 2,4-dinitrophenylhydrazone by liquid chromatography. Anal Chim Acta 467(1-2):97-103. https://doi.org/10.1016/S00032670(02)00130-7

Oztetik E (2015) Biomarkers of ecotoxicological oxidative stress in an urban environment: using evergreen plant in industrial areas. Ecotoxicology 24:903-914. https://doi.org/10.1007/s10646-0151433-9

Palmieri MJ, Luber J, Andrade-Vieira LF, Davide LC (2014) Cytotoxic and phytotoxic effects of the main chemical components of spent pot-liner: a comparative approach. Mutat Res Genet Toxicol Environ Mutagen 763:30-35. https://doi.org/10.1016/ jmrgentox 201312008

Phoungthong K, Shao LM, He PJ, Zhang H (2018) Phytotoxicity and groundwater impacts of leaching from thermal treatment residues in roadways. J Environ Sci 63:58-67. https://doi.org/10.1016/ jjes201611009

Phoungthong K, Zhang H, Shao LM, He PJ (2016) Variation of the phytotoxicity of municipal solid waste incinerator bottom ash on wheat (Triticum aestivum L) seed germination with leaching conditions. Chemosphere. https://doi.org/10.1016/ jchemosphere201512063

Praveen A, Pandey C, Khan E, Gupta M (2017) Selenium enriched Garden gress (Lepidium sativum L): role of antioxidants and stress markers. Rus Agric Sci 43(2):134-137. https://doi.org/10. 3103/s1068367417020033

Quilici L, Praud-Tabaries A, Tabaries F, Siret B (2004) Integration of ecotoxicity index and carboxylic of MSW incineration bottom ashes. Ecotoxicology 13(6):503-509. https://doi.org/10.1023/B: ECTX00000371878496489

Ramírez WA, Domene X, Andrés P, Alcañiz JM (2008) Phytotoxic effects of sewage sludge extracts on the germination of three plant species. Ecotoxicology 17(8):834-844. https://doi.org/10.1007/ s10646-008-0246-5 
Journal of Law (2015) Regulation of the Minister of Economy of 16 July 2015 on the admission of waste for landfill (Journal of Law, item 1277)

Rout JR, Behera S, Keshari N, Ram SS, Bhar S, Chakraborty A, Sudarshan M, Sahoo SL (2015) Effect of iron stress on Withania somnifera L: antioxidant enzyme response and nutrient elemental uptake of in vitro grown plants. Ecotoxicology 24(2):401-413. https://doi.org/10.1007/s10646-014-1389-1

Salihoglu G, Pinarli V (2008) Steel foundry electric arc furnace dust management: Stabilization by using lime and Portland cement. J Hazard Mater 153(3):1110-1116. https://doi.org/10.1016/jjhazma t200709066

Seneviratne M, Rajakaruna N, Rizwan M, Madawala HMSP, Ok YS, Vithanage M (2019) Heavy metal-induced oxidative stress on seed germination and seedling development: a critical review. Environ Geochem Health 41(4):1813-1831. https://doi.org/10. 1007/s10653-017-0005-8

Siddiquea R, Kaur G, Rajor A (2010) Waste foundry sand and its leachate characteristics. In: Resources, Conservation and Recycling. Vol 54, 12, Elsevier BV, pp 1027-1036. https://doi.org/10. 1016/jresconrec201004006

Škvára F, Kaštánek F, Pavelková I, Šolcová O, Maléterová Y, Schneider P (2002) Solidification of waste steel foundry dust with Portland cement. J Hazard Mater 89(1):67-81. https://doi.org/10. 1016/S0304-3894(01)00294-1

Stevens DP, McLaughlin MJ, Alston AM (1998) Phytotoxicity of the fluoride ion and its uptake from solution culture by Avena sativa and Lycopersicon esculentum. Plant Soil. https://doi.org/10.1023/ A: 1004392801938

Stevens DP, McLaughlin MJ, Randall PJ, Keerthisinghe G (2000) Effect of fluoride supply on fluoride concentrations in five pasture species: Levels required to reach phytotoxic or potentially zootoxic concentrations in plant tissue. Plant Soil 227(1-2):223-233. https://doi.org/10.1023/A:1026523031815
Strobos JG, Friend JFC (2004) Zinc recovery from baghouse dust generated at ferrochrome foundries. Hydrometallurgy 74 (1-2):165-171. https://doi.org/10.1016/jhydromet200403002

Tiquia SM (2000) Evaluating phytotoxicity of pig manure from the pig-on-litter system. Proceedings of the International Composting Symposium (ICS'99), Vol 1, 625-647

Visioli G, Conti FD, Gardi C, Menta C (2014) Germination and root elongation bioassays in six different plant species for testing $\mathrm{Ni}$ contamination in soil. Bull Environ Contam Toxicol 92 (4):490-496. https://doi.org/10.1007/s00128-013-1166-5

Wang C, Tian Y, Wang X, Geng J, Jiang J, Yu H, Wang C (2010) Lead-contaminated soil induced oxidative stress, defense response and its indicative biomarkers in roots of Vicia faba seedlings. Ecotoxicology 19(6):1130-1139. https://doi.org/10. 1007/s10646-010-0496-x

Wang F, Song N (2019) Salinity-induced alterations in plant growth, antioxidant enzyme activities, and lead transportation and accumulation in Suaeda salsa: implications for phytoremediation. Ecotoxicology 28(5):520-527. https://doi.org/10.1007/s10646019-02048-8

Wierzbicka M, Bemowska-Kałabun O, Gworek B (2015) Multidimensional evaluation of soil pollution from railway tracks. Ecotoxicology 24(4):805-822. https://doi.org/10.1007/s10646015-1426-8

Yu XZ, Gu JD (2007) Differences in Michaelis-Menten kinetics for different cultivars of maize during cyanide removal. Ecotoxicol Environ Safety 67(2):254-259. https://doi.org/10.1016/ jecoenv200606009

Zucconi F, Pera A, Forte M, De Bertoldi M (1981) Evaluating toxicity of immature compost. BioCycle 22(2):54-57

Zucconi F, Monaco A, Forte M (1984) Phytotoxins during the stabilization of organic matter. In: Gasser JKR (ed). Composting of agricultural and other wastes. Elsevier, New York, pp 73-88 